\section{SOI: $1.1 /$ TAS DOI: $10.15863 /$ TAS International Scientific Journal Theoretical \& Applied Science}

p-ISSN: 2308-4944 (print) e-ISSN: 2409-0085 (online)

Year: $2018 \quad$ Issue: $06 \quad$ Volume: 62

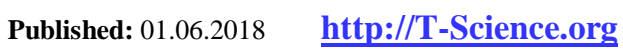

Makhamedkali Kenzhekhojayev Candidate of Technical Sciences, Associate professor Head of the department «Technology of food products, processing industries and biotechnology»

M.Kh. Dulaty Taraz State University, Kazakhstan

SECTION 23. Agriculture. Agronomy. The technique.

\title{
PHYSICO-CHEMICAL AND MICROBIOLOGICAL INDICATORS OF LACTULOSE AND GALACTOOLIGOSACCHARIDES USED IN THE FERMENTATION OF MILK
}

\begin{abstract}
Fermented milk products are obtained by fermenting milk or cream with pure cultures of lactic acid bacteria, sometimes with the participation of yeast and acetic acid bacteria. In the process of fermentation, complex microbiological and physicochemical processes take place, as a result of which the taste, smell, consistency and appearance of the finished product are formed.

Thus, the study of the issue of obtaining a variety of starter cultures for the production of lactic acid products, both on the basis of lactobacilli and bifidobacteria, is extremely topical in the sphere of providing the population with high-quality, functional and inexpensive food products.

Key words: strain, bacterial ferments, lactic acid bacteria, lactulose, galactooligosaccharides.

Language: English

Citation: Kenzhekhojayev M (2018) PHYSICO-CHEMICAL AND MICROBIOLOGICAL INDICATORS OF LACTULOSE AND GALACTOOLIGOSACCHARIDES USED IN THE FERMENTATION OF MILK. ISJ Theoretical \& Applied Science, 06 (62): 20-23.

Soi: http://s-o-i.org/1.1/TAS-06-62-4 Doi: crossef https://dx.doi.org/10.15863/TAS.2018.06.62.4
\end{abstract}

\section{Introduction}

Throughout the world, there has been a steady trend in the production and consumption of functional products, most of which are products of probiotic fermented milk. These products, which include microorganisms and substances of microbial origin, have a beneficial effect on the physiological functions and biochemical reactions of the human body by optimizing its microbiological status.

For human health and maintaining the vital activity of the human body, balanced nutrition of high quality is essential, which is necessary both for the normal functionality of the organism as a whole and for creating resistance to harmful environmental factors. The very notion of "nutrition" can be regarded as a factor in the regulation of the metabolism, and certain food substances - as its sources, differentiated in its effect. At the heart of modern nutrition concepts is the theory of balanced nutrition, which is necessary for determining human needs for food by energy, plastic and other components, and is also used to develop regimes of rational nutrition of different population groups, taking into account physical activity and functional state $[1,3,7]$.
Present day, the population of many countries, including in the RK, badly needs to increase the amount of food consumed, rich in protein, and compensate for the deficiency of essential amino acids, vitamins and trace elements. Various technological solutions in the field of large-scale industrial production and application of natural biocorrectors open new stages of scientific and technical progress not only in our country, but also for the entire world community. Such bioproducts have a high competitive ability in the world market due to $100 \%$ naturalness, guarantee of harmlessness, high biological and socio-economic importance, and also a rather low cost price [2,5].

New approaches to the composition, properties, and, consequently, the technologies for the production of food products with functional properties, should be developed taking into account all the requirements of the organism in all nutrients and energy [4,6]. Functional products intended for dietary and preventive nutrition differ from conventional products in terms of chemical composition, energy and biological value, physiological properties, and the content of certain nutrients $[8,12,13]$. 
It is known that virtually any product in native form is not able to fully meet the need for major human food ingredients, vitamins, minerals. Therefore, in recent years, food technology has noted a tendency to develop and introduce the production of specialty food products enriched with proteins, dietary fiber, trace elements and vitamins. All this allowed to create a whole range of new advanced technologies and products, significantly expanding their range.

Milk and dairy products are among the most common foods included in rations of all categories of the population. This is due to the unique composition and properties of milk, as well as the ability to produce from it a large number of various foods. Milk serves as a good basis for creating combined products $[3,11]$. Combining the process of adding raw materials of vegetable and animal origin to milk, while enriching the food with fiber, vitamins and minerals. Such products are not only useful and easily digestible, but also universal, diverse and every day.

Of great interest is the use in the production of fermented probiotic products to restore intestinal microflora in combination with prebiotics and natural ingredients of plant origin. [9]

The main advantage of fermented milk products is the content of lacto- and bifidobacteria in them, which contribute to a decrease in the amount of pathogenic and putrefactive bacteria that poison the human body in the intestine $[1,10,14]$.

The aim of the work is the study of lactic acid starter cultures based on lactobacilli in the production of lactic acid products using prebiotics.

In recent years various dairy products have been developed and patented - beverages, sour cream, sour cream and curd products, which contain lactulose. The main purpose of introducing this prebiotic is to impart functional properties to the products, however, manufacturers can additionally obtain a whole series of positive effects

- increased survival of starter microflora during long-term storage and freezing;

- increase in the shelf life of products;

- improving the consistency of products

The physicochemical and microbiological indices of lactulose and galactooligosaccharides were studied. The results are presented in tables 1 and 2 .

\section{Physicochemical and microbiological indicators of lactulose}

Table 1

\begin{tabular}{|l|c|}
\hline \multicolumn{1}{|c|}{ Indicator name } & Lactulose \\
\hline Mass fraction of lactulose in the volume (g / ml), \% & 66,7 \\
\hline Mass fraction of dry substances, \% & 60,7 \\
\hline Mass fraction of other carbohydrates, \% & 11,3 \\
\hline $\begin{array}{l}\text { The number of mesophilic aerobic and facultative anaerobic } \\
\text { microorganisms in 1 g of CFU product }\end{array}$ & Less than 5000 \\
\hline Bacteria of E. coli group in 1 g of product & Not detected \\
\hline Number of mold fungi in 1 g of CFU product & Less than 100 \\
\hline The amount of yeast in 1 g of CFU product & Less than 50 \\
\hline
\end{tabular}

\section{Physicochemical and microbiological indicators of galactooligosaccharide preparations}

Table 2

\begin{tabular}{|l|c|}
\hline \multicolumn{1}{|c|}{ Indicator name } & Galactooligosaccharide \\
\hline Appearance and color & White powder \\
\hline Taste & Sweet, without foreign tastes \\
\hline Moisture content, $\%$ & 2,4 \\
\hline $\begin{array}{l}\text { Content of active } \\
\text { substance (GOS), } \%\end{array}$ & 5,0 \\
\hline pH (for 10\% solution) & Less than 50 \\
\hline Total number of bacteria, CFU CFU / g & Less than 30 \\
\hline Coliform, CFU / 100 g & Not detected \\
\hline Pathogenic microorganisms & \\
\hline
\end{tabular}

Effect of lactulose on the properties of fermented milk products and the development of mesophilic lactococci 
The influence of lactulose on the development of starter microflora during ripening.

At this stage of work, the effect of lactulose on the development of starter microflora during fermentation, as well as on the organoleptic characteristics and viscosity of two different mixtures for the sour milk drink, was studied.
According to the data on the highest survival of the cells of the ferment microflora under conditions of low temperature effects, LAT CW and lactulose in the amount of $3 \%$ were used in experimental studies.

The work was carried out with the leaven of mesophilic Lactobacillus LAT CW, the characteristic of which is presented in table 3 .

Characteristics of the leaven LAT CW L

Table 3

\begin{tabular}{|l|c|}
\hline \multicolumn{1}{|c|}{ Starter designation } & LAT CW L \\
\hline Manufacturer & ECOCOM, Bulgaria \\
\hline Species composition & $\begin{array}{c}\text { Lactococcus lactis subsp. lactis, Lactococcus lactis subsp.cremoris, } \\
\text { Lactococcus lactis subsp. lactis biovar diacetilactis. }\end{array}$ \\
\hline Ripening temperature, ${ }^{\circ} \mathrm{C}$ & $28-30$ \\
\hline Ripening time, $(\mathrm{pH} 4.5), \mathrm{h}$ & $14-18$ \\
\hline Acid-forming activity, ${ }^{\circ} \mathrm{T}$ & 80 \\
\hline Sensory evaluation & Expressed taste, aroma and viscous consistency \\
\hline Number of viable cells, $\mathrm{CFU} / \mathrm{g}$ & $10^{10}$ \\
\hline
\end{tabular}

Lactulose is used in the metabolism of starter microflora and affects the properties of fermented milk products, and the result of this effect depends both on the composition of the ferment and on the concentration of lactulose. Thus, for example, the introduction of lactulose at a concentration of (1 $5) \%$ did not have a significant effect on the patterns of acid formation, the duration of fermentation and the post-acidification of fermented milk products prepared using this starter, but reduced the rate of acid formation.

The effect of lactulose on the change in titratable acidity during the fermentation of samples of mixture $A$

\begin{tabular}{|c|c|c|c|c|}
\hline \multirow[b]{2}{*}{ Sample } & \multicolumn{4}{|c|}{ The average value of the titrated acidity, ${ }^{\circ} \mathrm{T}$} \\
\hline & $\begin{array}{l}\text { After applying the } \\
\text { ferment }\end{array}$ & After 2 hours & After 4 hours & After 6 hours \\
\hline Mixture A, control & $16 \pm 2$ & $47 \pm 2$ & $81 \pm 2$ & $101 \pm 2$ \\
\hline $\begin{array}{l}\text { Mixture A, experiment }(3 \% \\
\text { lactulose) }\end{array}$ & $16 \pm 2$ & $60 \pm 2$ & $93 \pm 2$ & $113 \pm 2$ \\
\hline Mixture B, control & $15 \pm 2$ & $37 \pm 2$ & $63 \pm 2$ & $93 \pm 2$ \\
\hline $\begin{array}{l}\text { Mixture B, an experiment (5\% } \\
\text { lactulose) }\end{array}$ & $15 \pm 2$ & $40 \pm 2$ & $72 \pm 2$ & $90 \pm 2$ \\
\hline
\end{tabular}

Analysis of the experimental results shows that the application of lactulose syrup has no effect on the initial acidity of the mixture, and the acid-forming activity of mesophilic lactic acid cocci depends on the composition of the mixture. Thus, in the experiments with the mixture A, the process of acidity increase was more effective in the presence of lactulose: after 4 hours of fermentation, the titrated
During the experiment, fermentation of the mixtures was carried out for 6 hours under optimal conditions for the development of the microflora of the ferment $(30 \pm 1)^{\circ} \mathrm{C}$. During the fermentation, the increase in the active and titratable acidity in the sample was monitored.

Table 4 shows the results of an experiment on the effect of lactulose on the change in titratable acidity during fermentation / mixtures A and B for a sour milk drink

Table 4

\section{and $B$ for the sour milk drink \\ reration of samples of mix}


and B for a fermented milk drink was carried out in terms of color, smell, consistency, taste and aftertaste. When evaluating the organoleptic parameters of the mixtures, a 5-ball system was used.

During the organoleptic evaluation of mixture A, it was noted that the sample with lactulose had a pleasant sour-milk taste and sweetness, compared to the sample without lactulose, which had an excessively expressed sour-milk taste. The color of the mixture for sour-milk ice cream with lactulose has an attractive creamy shade.

The consistency of samples of mixture A was not homogeneous, the presence of flocculating protein clots was noted. Sample mixture B had a pure sour taste, without foreign flavors and odors, a uniform consistency.

\section{Conclusion}

The whole process of production of fermented milk products, as well as the quality of the finished product, depends on the quality of the ferment. From the used starter cultures, the taste of the product and its texture depend. Today, a huge number of starter cultures, consisting of one kind of microorganisms or from their combinations, allows you to create a product with almost any specified characteristics.

The results obtained in the study of the effect of lactulose on the properties of mixtures for the sour milk drink, suggest that the prebiotic has a positive effect on the process of fermentation of the samples in terms of the formation of consistency and taste. However, the method for preparing mixture A for the sour milk beverage had its drawbacks, since the mixture with carrageenan is difficult to pasteurize, and after fermentation the mixture was not homogeneous and tended to separate. Apparently, you need to use a different stabilizer.

\section{References:}

1. Stepanenko P. P. (2002) Microbiology of milk and dairy products.-M .: Lira, 2002.- p.413.

2. Bannikova L.A, Koroleva N.S, Semenikhina V.F. (2007) Microbiological basis of dairy production. - Moscow: Agropromizdat, 2007. p.400.

3. Koroleva N.S, Semenikhina V.F. (2003) Sanitary microbiology of milk and dairy products. - Moscow: Food Industry, 2003. p. 256 .

4. (1998) Microbiology of products of animal origin. Münch, X. Saupe, M. Schreiter et al. / Transl. with him. E.G. Turner ed. Doctor of Biological Sciences N.S. Queen, Cand. Biol. Nauk N.V. Biletova, Candidate of Sciences R.P. Kornelayeva .- Moscow: Agropromizdat, 1998. - p.591.

5. Polishchuk PK, Derbinova E.S., Kazantseva N.N. (2006) Laboratory workshop on the microbiology of milk and dairy products. Moscow: Light and food industry, 2006. p.200.

6. Bannikova, L.A. (2005) Selection of lactic acid bacteria and their use in the dairy industry. [Text] / LA Bannikova .- M: "Food Industry", 2005. - p.255.

7. Glushanova, N.A. (2003) Biological properties of lactobacilli. [Text] / N.A. Glushanova // Bulletin of Siberian Medicine. - 2003. - T. 2. p.50-58.

8. Irkitova, A.N. (2011) Methods for determining the antagonistic activity of lactic acid bacteria [Text] / AN Irkitova, Ya.R. Kagan-Barnaul:
GNU Siberian Research Institute of Cheese Making of the Rosselkhozakademii, 2011 p. 10 .

9. (2011) The Incompetent, K.V. Investigation of biochemical and morphological properties of strains of bacteria of the genus Lactobacillus [Text] / K.V. Bespomestnykh, A.G. Galstyan, E.V. Short // Technology and technology of food production. - 2011. - p.5-10.

10. Novokshonov, A.A. (2013) Physiological functions of lactobacilli in the body and the effectiveness of their use in the composition of probiotics in pediatric practice [Text] / A.A. Novokshonov, N.V. Sokolova // Effective pharmacotherapy. - 2013. - T.54. - p.20-25.

11. Netrusov, A.I. (2005) Practical work on microbiology [Text] / AI Netrusov, MA Egorova, LM Zakharchuk. - M .: Publishing Center "Academy", 2005. - p.608.

12. Pulcherovskaya, L.P. (2010) Methodical instructions to the lagatory-practical studies on discipline "Probiotics" [Text] /L..P.Pulcherovskaya, D.A. Vasiliev, S.N. Zolotukhin. - Ulyanovsk: Ulyanovsk State Agricultural Academy, 2010.- p.70.

13. Kvasnikov, E.I. (1975) Lactic acid bacteria and ways of using them. [Text] / E.I. Kvasnikov, O. A. Nesterenko. - Moscow: "Science", 1975. p.384.

14. Zakharova, N.G. (2012) Microbiology in definitions and illustrations [Text] / N. G. Zakharova, V.I. Vershinina, ON Ilinskaya. Kazan: Publishing house "Feng", 2012. - p.799. 